\title{
Algorithm Governance Framework for Media Regulation in Nigerian Media System
}

\author{
Abdullahi Saleh Bashir ${ }^{1 *}$ \\ ${ }^{1}$ Department of Information Technology, Modibbo Adama University of Technology, \\ Yola, Adamawa State, Nigeria. \\ P.M.B. 2076, Yola Adamawa State Nigeria \\ Email: asbashir@mautech.edu.ng
}

\begin{abstract}
The world of media and information, from the time internet became popular, has been in constant rapid changes to such an extent that older models of conventional media system are being challenged if not replaced. One of the changes being experienced in the contemporary media environment is the use of computer codes or algorithms to perform gatekeeping functions that used to be done solely by human agents. This paper reviews the state and challenges of media regulations and the use of algorithms in Nigerian media system. The review showed a gap in media regulation in Nigeria where journalism is compartmentalised in contrast to media convergence and that algorithmic-based journalism may not be effectively regulated. To close this gap, the study used risk-based analysis as a theoretical framework and library research as method to design a framework for algorithmic media governance in the country. The result is the Converged Media Governance Framework for Algorithmic and Mixed Journalism. The framework reconceptualizes the way and manner media regulation is framed and organised as involving only human agents and alsothat journalism in the country should not be compartmentalised in the light of media convergence. The paper recommended the adoption of the framework by stakeholders in the Nigerian media system.
\end{abstract}

Keywords: algorithm governance, regulation, system, Nigeria

\begin{abstract}
Abstrak
Dunia media dan informasi, sejak internet menjadi populer, telah mengalami perubahan yang cepat sedemikian rupa sehingga model sistem media konvensional yang lama tertantang jika tidak diganti. Salah satu perubahan yang dialami dalam lingkungan media kontemporer adalah penggunaan kode komputer atau algoritma untuk melakukan fungsi penjaga gerbang yang dulu hanya dilakukan oleh agen manusia. Makalah ini mengulas keadaan dan tantangan regulasi media dan penggunaan algoritma dalam sistem media Nigeria. Tinjauan tersebut menunjukkan adanya celah dalam regulasi media di Nigeria di mana jurnalisme dikotakkan berbeda dengan konvergensi media dan bahwa jurnalisme berbasis algoritmik mungkin tidak diatur secara efektif. Untuk menutup kesenjangan ini, penelitian ini menggunakan analisis berbasis risiko sebagai kerangka kerja teoritis dan penelitian perpustakaan sebagai metode untuk merancang kerangka kerja tata kelola media algoritmik di negara ini. Hasilnya adalah Kerangka Tata Kelola Media Konvergen untuk Jurnalisme Algoritma dan Campuran. Kerangka ini merekonseptualisasikan cara dan tujuan regulasi media dibingkai dan diorganisasikan sebagai pelibatan hanya agen manusia, dan jurnalisme di negara tersebut tidak boleh
\end{abstract}


Bashir: Algorithm Governance Framework

for Media Regulation in Nigerian Media

Sys t e m

dikotak-kotakkan dalam terang konvergensi media. Makalah ini merekomendasikan adopsi kerangka kerja oleh para pemangku kepentingan dalam sistem media Nigeria.

Kata kunci: tata kelola algoritma, peraturan, sistem, Nigeria

\section{INTRODUCTION}

In the second week of December 2018, a story broke out from the United States Congress investigation on social media misuse during their own last general election. A congressman asked a CEO why is it that if the word 'idiot' is searched on google image (or photo) search, the picture of President Donald Trump appears. Also, negative news stories appear whenever 'health care bill' is searched. Google chief executive Sundar Pachai was asked the reason for this anomaly. His response is that google search engine is not done by human beings (it is done by algorithm) and that it brings out result based 200 parameters including relevance and popularity. Because of that there is little or nothing they can do about it. Facebook had exhibited similar issue when fake news posts are directed or targeted to particular individuals or groups obviously to influence their views on some issues. Still Facebook officials argue that it is not personal or done by their staff but rather selected by their algorithm. How true is it that there is nothing they can do and as such, the world is at the mercy of algorithm?

Analysts in the computer world have predicted that a lot of the activities that human beings used to do manually are likely to be done by computerized machines. This is largely due to advancement in artificial intelligence, big data analytics, mobile telephony and IT in general. Many activities have moved online as internet penetration is becoming more of a necessity of $21^{\text {st }}$ century life. Not only are financial and business services conducted largely online but nowadays many domains of human activities are moving online. This massive shift to online environment has a number of implications for individuals organisations and the society.

In this current age of internet, the importance of data cannot be over emphasized and data which has been described as the 'new gold' of the $21^{\text {st }}$ century. WEF 2011 is necessary for innovation and economic success as London Economics 2010. To manipulate our data to make money, these online platforms create and use powerful algorithms behind the scene and for searching, 
aggregation, surveillance, forecast, filtering, recommendations, scoring, content production and allocation (Saurwein, Just, and Latzer 2015). These algorithms have taken the place of earlier less intrusive physical, mechanical and electronic technologies (Manovich 2014) which relied on human decision making and therefore have no governing powers in themselves. So, instead of some workers sitting behind a desk to monitor, approve, control, manage, etc it is machines that do these (Lazer, Kennedy, King, and Vespignani 2014) identified the various types of algorithms based on their functions and their common examples (see Table 1).

While the above are generalised domains, algorithm journalism, also called software generated journalism, robot journalism, artificial intelligence news, software generated news, automated journalism, bot driven or data driven journalism have widely diffused in the field of journalism especially in north America and Europe (Lindén 2017) and thereby performing secondary agenda setting and gatekeeping roles Bakker 2012 (Just and Latzer 2017). Associated Press, Forbes, Los Angeles Times and Pro Publica are among the popular media organisations using algorithmic journalism (Graefe 2016). Accordingly, algorithm journalism which widely deployed in sports and business news domains is deployed either as sole (automated) agents or mixed human computer journalism. Algorithms is not only diffusing into the newsrooms but according to Linden, is having disruptive effect on the normative foundations of journalism. One of the areas that algorithm is disrupting is the regulatory framework with which journalism is governed. 
Bashir: Algorithm Governance Framework

for Media Regulation in Nigerian Media

S y s t e m

Table 1

\begin{tabular}{|c|c|}
\hline Types & Example \\
\hline \multicolumn{2}{|c|}{ Search General search engines (e.g. Google search, Bing, Baidu) } \\
\hline Special search engines & (e.g. Mocavo, Shutterstock, Social Mention) \\
\hline Meta search engines & (e.g. Dogpile, Info.com) \\
\hline Semantic search engines & (e.g. Yummly) \\
\hline \multicolumn{2}{|c|}{ Question and answer services (e.g. Ask.com) } \\
\hline \multicolumn{2}{|c|}{ Aggregation News aggregators (e.g. Google News, nachrichten.de) } \\
\hline \multicolumn{2}{|c|}{ Observation/surveillance Surveillance(e.g. Raytheon's RIOT) } \\
\hline Employee monitoring & (e.g. Spector, Sonar, Spytec) \\
\hline General monitoring software & (e.g. Webwatcher) \\
\hline \multicolumn{2}{|c|}{ Prognosis/forecast Predictive policing (e.g. PredPol), } \\
\hline \multicolumn{2}{|c|}{ Predicting developments: success, diffusion, etc. (e.g. Google Flu Trends, scoreAhit) } \\
\hline Filtering Spam filter & (e.g. Norton) \\
\hline Child protection filter & (e.g. Net Nanny) \\
\hline \multicolumn{2}{|c|}{ Recommendation Recommender systems (e.g. Spotify; Netflix) } \\
\hline \multicolumn{2}{|c|}{ Scoring Reputation systems: music, film, etc. (e.g. ebay's reputation system) } \\
\hline News scoring & (e.g. reddit, Digg) \\
\hline Credit scoring & (e.g. Kreditech) \\
\hline Social scoring & (e.g. Klout) \\
\hline \multicolumn{2}{|c|}{ Content production Algorithmic journalism (e.g. Quill; Quakebot) } \\
\hline \multicolumn{2}{|c|}{ Allocation Computational advertising (e.g. Google AdSense, Yahoo! Bing Network) } \\
\hline Algorithmic trading & (e.g. Quantopian) \\
\hline Source: Latzer et al. 2015 in (Sa & urwein et al. 2015) \\
\hline
\end{tabular}

Functional Typology of Algorithmic Selection Applications

Looking at the functions that algorithms perform and the power they are amassing, many analysts are questioning and even challenging their power over our lives and our professions. We have seen how Facebook algorithm was used to manipulate message British citizens were exposed to social media during the Brexit debate, the last United States general election and the Nigerian 2015 general elections. There were lots of manipulations and trending fake news because some third parties were able to access and tweak algorithms of various social media platforms. Criminal hackers too can take advantage of these algorithms by hacking into them to inflict damages to users.

While the concerns about the enormous power of algorithms is well known across the globe especially as result of the rise of populism, fake news, hate speech and numerous abuses of users' data on numerous platforms like Google and Facebook, the regulatory response to such misuse andabuses especially in developing countries are not well articulated to suit the current challenge. The conventional mass media in mostcountries is regulated through 
brick and mortar regulatory mechanisms that works on the assumption that human agency (as individuals and organisations) alone are the actors. However, with algorithmic journalism, computer algorithms (or computer software) are increasing playing the role of journalists or complementing them.

According to (Apuke 2016) ICTs has taken roots in Nigerian mass sector in present day Nigerian journalism with many organisations using computer and computer networks. Large number of Nigerian media are also using internet with content and activities done online (Talabi 2011). The adoption of ICTs by the media is a prelude to the introduction of algorithmic journalism in every society.

In Nigeria the earliest known use of algorithm or robot to generate news stories in public domain was when Fintel Envoy - a bot - was developed in 2018 by an organization known as Orodata Science for financial information reporting using structured data collected by the Nigerian Inter-Bank Settlement System (Aboh 2020). The bot generates short news stories on payment channels and banking sector credits. The same organization also developed an algorithm called Arria to generate hundreds of stories from structured election data in Nigeria. Another use of algorithm or robot for information in a quasi-journalistic way in Nigeria by BudgiT, an organisation aimed at promoting financial accountability in public domain. The organisation autogenerate some reports adding graphics and interactive features to make government budgets in Nigeria 'readable' to various segments of the public. With two million views and 275,000 unique visitors as at 2014, BudgiT also works with journalists so thereby making their contents accessible to the public (Onigbinde 2014).

While for now mainstream media organisations are yet to adopt algorithm journalism to write stories, the diffusionist tendencies of such technologies won't take long time to find their way into newsroom in the country. However, stories generated by algorithm in quasi-journalistic and non-journalistic entities find their way into news and hence the need for an effective framework for algorithmic governance (Ndlela 2020). Stated that in Africa algorithms - bots and trolls - are deployed to influence political outcomes during elections which endangers democracy in the continent. One of the institutions which serve as a victim of negative is the mass media which are left with reduced credibility and relevance. Some of the fake information generated by Cambridge Analytica, the infamous found their way into mainstream media in Nigeria during the 2015 general thus 
Bashir: Algorithm Governance Framework

for Media Regulation in Nigerian Media

Syste m

making it election to become one of the most divisive in the history of the country (Oparah 2015; Apuke 2018) also noted the use of computational algorithms and networks for propaganda especially during election campaign in many countries including Nigeria.

At a conference aimed at combating misinformation and disinformation, a Nigerian journalist in painting how challenging the situation is was quoted as saying:

people tend to believe whatever they see on Facebook and Twitter
more. And the tech guys such as Google, Twitter are not helping the
matter. They created monsters they cannot regulate, you cannot
control over 40 million people in Nigeria, you ask a robot to perform
the same function. We have less than 300 radio stations in the country
which are regulated but on Facebook we have over 40 million people
dishing out whatever they like, whenever they like....(Adenekan 2019).

In view of the use of algorithm by quasi-journalistic organisations in Nigeria who also feed journalists in media organisations with information, there is the important need to identify regulatory gaps and proffer possible solutions. Such role, which may be minor for now, may likely grow as is seen in other developing countries. This is significant because algorithms can now be said to be potential future of journalism every including Nigeria. However, issues of regulations or governance are better dealt with normatively with each society having its own unique environment. The aim of this paper therefore is to examine the current status of algorithm governance in Nigerian media landscape and identify an appropriate framework for governing algorithms in journalistic domain. Algorithms are man-made artefacts which originate or contribute to journalists' efforts. As such, the society must have measures with appropriate sanctions to control their use and misuse. Previous studies on media regulation in Nigeria focus on human dimensions of media regulation with no researches on algorithmic or human algorithmic journalism.

This study focuses on regulatory framework for algorithmic and humanalgorithmic (combined) regulation. Another, new dimension that have not been given focus is the separated organization of media regulation in the country with print media being separated with broadcast and online media. Technological convergence is making the media to become unified with multimedia contents. 
Media regulation in Nigeria is derived from the constitution which allows for the freedom of expression, the press and other freedoms allied to the information and communication. In addition to the constitution, numerous laws and regulations including judicial interpretations, regulations and codes made by agencies established by laws. Agencies like National Broadcasting Commission, Nigerian Institute of Public Relations, Nigerian Copyright Commission, Consumer Protection Council, Adverting Practitioners Council of Nigeria, among others also provide guidelines from time so as to regulate the media sector. These are the public regulation framework in the country that makes binding rule, enforce regulations and impose sanctions. However, in addition to the public regulation mechanism the media industry also regulate itself (self-regulation). This is implemented by associations and professional groups that provide guidelines and set up mechanisms for compliance and sanctions. Principally, the umbrella boy of the country's journalists, the Nigerian Union of Journalists (NUJ) in conjunction with Nigerian Guild of Editors (NGE) and Newspapers Proprietors Association of Nigeria (NPAN) have their various codes of ethics which members are expected to comply. These ethics are framed with individuals in mind (not artefacts like algorithms). In addition, the Nigerian Press Council (NPC), as a government established organization expected to work as co-regulatory agency. However, the performance of the council left much to be desired largely due to mistrust by stakeholders (Maho 2013). This has contributed to high level of unethical practices in Nigerian journalism especially corruption (Adeyemi 2013) and journalism being manned by many quacks (Talabi and Ogundeji 2012).

Overall scholars as stated below have argued that the media regulation in Nigeria has not lived up to expectation in fulfilling the need for regulating contents and practitioners that have erred (Maho 2013); (Ekeanyanwu and Obianigwe 2012; Nwabueze 2010). A number of unwholesome practices by journalist like corruption, politicization of news, lack of objectivity, divisive tendencies, character assassination, etc are common. Unfortunately, these ethical violations are hardly sanctioned and hence they are more likely to continue. Another dimension to the failure of the Nigeria media regulatory mechanisms is what Bertrand (nd) in (Ifeduba 2014) referred to as the too much focus on the individual journalists instead of media owners who hold real media power. However, media laws and codes including that of Nigeria focus on journalists 
Bashir: Algorithm Governance Framework

for Media Regulation in Nigerian Media

Sys t e m

who commit "minor sins" rather than media owners who commit "mortal sins". That is media proprietors are more likely to be major culprits but the laws and codes targets journalist. In addition, the laws and codes have their own internal inadequacies (procedures, remedies, etc). Therefore, with these regulatory challenges, how can and to what extent can algorithm journalism be governed in Nigeria?

It can be noted that the existing media regulatory framework in Nigeria cannot function effectively in a digitally connected, automated and converged setting existing now in the country. Talabi had earlier noted the regulation of mass media that have now converged many of which are active in Nigeria. He added that this is a new challenge that needs to be tackled in the age of internet journalism in Nigeria (Talabi 2011). The digital environment presupposes the interconnection of media irrespective of location some of whom operate using multimedia platforms that cannot be simply categorized solely as print, broadcast, advertising and public relations. In addition, the issue of automation (facilitated by algorithms) and handling of massive amount of user data. Huge amount of individual and corporate data are collected by media firms on the internet in the course of online communication. These data can be inform of text, video, photos, audios amongst others and can be used by those who collect them for many purposes including marketing, sales, advertisement, customer service, sale to third parties, service improvements, etc. (Just and Latzer 2017). This can open room for data abuse by the entities that collect them or by the third parties that access them. The current media regulation mechanism in Nigeria therefore need to reviewed to handle such challenges. Ndlela reports that social media like Facebook while important to citizen's and journalists, can are used to massively disseminate fake and misleading information. Introna and Nissenbaum (2000) also found out that search engines like google are manipulated by the wealthy and technologically savvy members of the society a result of which makes them to produce distorted results. As a result of these and other problems, many countries are implementing different regulation to counter their own form of risks and Nigeria too should not be an exception.

Nigeria has a number of legislations aimed at protecting the end users of computer and other users. These laws are largely crafted to protect users' data; 
privacy, unethical use, exploitation, access, etc (see Table 2). It can also be seen that in the age convergence media regulation is not connected with data protection laws with each operating without complementarity. Also, the two frameworks do not tackle the computer codes (algorithm) and how they are deployed to lead to bias, censorship, social discrimination, abuse of market power, effect on cognitive capabilities, violation of property rights, etc. Thus, if not governed effectively, algorithms can be programmed to work for the interest of the few and therefore in conflict with the interest of society. The fact that algorithms can be selfishly deployed with negative outcome simplies an appropriate form of regulation from within the industry and by authorities.

Table 2

\begin{tabular}{ll}
\hline Protection Law & \\
\hline - Section 37 of the constitution & 37 \\
- Child right acts 2003 & 2003 \\
- Freedom of Information Act No.4 of 2011 & 2011 \\
- The Cybercrimes Act 2011 & 2011 \\
- CBN Consumer protection framework & 2007 \\
- NITDA Guidelines on data protection, etc & \\
\hline
\end{tabular}

Data Protection Laws in Nigeria

Algorithms are computer formula designed to solve some problems following sequences of steps. They are the codes that make our computers, mobile phones, websites and other IT artefacts to work, thereby, enabling automation which has the advantage of speed, accuracy and saving human energy especially in routine, laborious and sometimes difficult tasks. The popularization of computing and internet has made algorithms to be widespread even though they operate behind the scene.

The diffusion of algorithm in the newsrooms has generated a number of researches on its perceptions and use (Lindén 2017) for instance, conducted an explorative study of computer (algorithm) journalism and how it may impact on the role of journalists, how journalists work along with other professionals (managers, programmers, etc) and the extent to which it can be used to relieve journalists of repetitive tasks. One of the fears of algorithm journalism is that it may lead to the laying off of journalists and the intrusion of computer experts into 
Bashir: Algorithm Governance Framework

for Media Regulation in Nigerian Media

Syste m

journalism. Linden declared that algorithm journalism is capable of automating only certain routine tasks of news work, which the author called 'low level journalism' especially in domains like sport and finance. However, journalistic work that requires passion and creativity which for now is not amenable to automation. Using expert interview method, He found out that while computer experts are enthusiastic about computer journalism which see journalists leasing part of their work to computers, journalists are concerned about lack of relevant computational skills and it will affect their job satisfaction. Secondly, the result show that algorithm journalism can free journalists from some routine tasks (e.g writing structured stories, news selection and placement, scheduling, queuing, among others) and they can be smarter with good use of algorithm. Thus, hybrid form of human-machine journalism is recommended.

Linden therefore concluded that computational (algorithm) journalism is a reality that journalists have to deal with to add value to their work. However, there are ethical, moral, and operational considerations with this. For instance, algorithms can be manipulated by its creators or others. Hence the need for framework to regulate their use in journalism.

Other researchers like Wölker and Powell analyzed the perceived users' credibility of automated and mixed (human-computer) written news stories among European audience. Using an experimental design of online readers in Europe, the study found out that there is no difference between automated journalism, human journalism and mixed one as far as message and source credibility is concerned in finance and sports news domain. The automated journalism stories actually score a little higher for message credibility in sports news which the researchers attributed to specific details provided which may not be easily recalled by human journalists. Despite the promising outcome for algorithmic journalism in the study, they are of the view that automated journalism cannot act as fourth estate of the realm (Wölker and Powell 2018). They therefore, argued along the line of (Stromback 2005) that journalism has a moral obligation to democracy which algorithms cannot fulfil. They therefore recommended mixed journalism. Although algorithm journalism is in its infancy in Nigeria and many developing countries, the issue of credibility and moral obligation may likely be universal 
with slight variations in details. Therefore, algorithm cannot replace human journalists and will still need to be regulated appropriately.

Looking at the reality of algorithm journalisms diffusion into many countries there is the need for appropriate regulatory framework to manage its benefit and risk. Latzer et al. citing other scholars identified nine categories of risks inherent with the use of algorithms. These include manipulation, biases and distortions of reality, surveillance, threat to data protection and privacy, social discrimination, violation of intellectual property rights, abuse of market power, effects on cognitive capabilities, growing heteronomy and loss of human sovereignty and controllability of technology. According to Grasser and Schulz cited in (Saurwein et al. 2015), there are a number of options to reduce the risks and increase the benefits of algorithm in general depending on the institution, capacity, and level of expertise. Therefore, the scholars recommended that the "governance perspective" is helpful in analysis, assessment and improved regulation of algorithm. Meanwhile, (Doneda and Almeida 2016) see algorithm governance as a combination of legal, regulatory and technical standards aimed at fostering accountability, transparency and technical assurance in the use of algorithm in a social system. They further added that there is no one size fits all as each society has its own peculiarities in risk and benefits.

However, the media convergence has made delimiting algorithm governance to only media domain as archaic and unrealistic. So, algorithm governance needs to be broad and cut across many domains that are similar to the mass media and need to be broad to include all actors (individual journalists, programmers, technicians, audience, etc. and organisations like service providers, marketers, host, public institutions, associations, and artefacts. it is the novelty of this research.

\section{METHODS}

As discussed above, algorithmic journalism has advantages but also comes with risks that can endanger society. According to Saurwein et al. 'from a public-interest point of view, governance should reinforce benefits and minimize risks. The benefits of algorithmic journalism include increased quantity of reporting, speed in content production and distribution, increased innovation, additional profits for media entrepreneurs, feeing journalists from drudgery of 
Bashir: Algorithm Governance Framework

for Media Regulation in Nigerian Media

Sys t e m

some work, more collaboration with computer experts, among many others (Verschuren and Hartog 2005). However, with the advantages also comes some risks: manipulation, censorship, fake news, low artistic creativity, inability to properly serve as fourth estate of the realm, tension in the relationship between journalists and machine, among many others. Therefore, this study adopts riskbased approach to govern algorithm in media system in Nigeria.

Risk-based regulation is a set of strategies or framework that entities wit regulatory powers adopt in order to focus on activities that pose risk their regulatory system to enable them achieve their objectives (Black and Baldwin 2012). The framework which has many variants requires identification of risks and ways to manage them instead of making recommending of following laws or regulations. The framework is being used in many fields of regulation like environment, health, financial services, education, the media and many other sectors. In the media sector, (Valcke, Picard, Sükösd, Klimkiewicz, Petkovic, Zotto, and Kerremans 2010) used the framework for designing media pluralism regulation in European Union. (Balule 2016) also analyzed the used of the framework in promoting and safeguarding media pluralism in Botswana. The researcher identified numerous risks to pluralism and concluded that there are inadequate laws to promote media pluralism in the country. Due to therisks of algorithms, scholars have proposed numerous ways in which societies can regulate their deployment in public domain. Saurwein et al. using a risk-based approach, identified five options to govern algorithms using a mix of government, self and market approaches. These options are:

1. Market solution and governance by design: this is a form of regulation in which market forces and structures can help to regulate or govern algorithms. This involves voluntary behaviour in market conduct by consumers and suppliers. Actions like change of service providers, market compensation, boycott, product innovation, incentive not to collect data, etc.

2. Option for industry: These are measures undertaken by industry actors either as self-organisations or industry wide self-regulation. These include industry standards, corporate social responsibility, minimum principles of data collection, quality control, ethics board, etc

3. Options for state interventions: this is the public regulatory mechanism that can include laws implemented by state agencies in can come in forms of laws, regulations, incentives, taxes/fees, subsidies/funding, awareness and support for appropriate behavior. 
In addition, (Just and Latzer 2017) explored the potentials of governance by algorithm and stated that algorithms themselves can be deployed as agents to perform governing functions especially on the internet. They added that the central trend of convergence in communication and the growing awareness of the power of computer programmes, algorithms can be considered as actor or agency that can create meaning by itself or as an institution with effect on individual, collective behavior and social order. For the mass media sector for instance, governance by algorithm, according to them, with the help of big data and machine learning, is more evidence-based and data driven. However, the dominance of private sector or market driven present risks that will need to be balanced with public policy considerations.

As a result of the gap in media regulation of algorithmic journalism in Nigeria, this research fills this gap by proposing a framework for media regulation in a converged media environment using algorithm, human agents or mixed journalism. The study uses qualitative library research and generate the framework (both graphically and conceptually) for algorithm governance in Nigeria. Secondary sources of data used for the study were generated from existing literature and the framework was generated and presented conceptually and graphically.

\section{RESULT AND DISCUSSION}

In response to the regulatory challenges and the technical and environmental changes in the Nigerian media ecology, this paper recommends converged media regulatory framework to govern algorithm and mixed journalism. Converged framework is essential to take care of various journalistic and meta-journalistic formats by human and non-human actors in all the various forms of conventional and online journalistic environment. This may lead to redefinition of journalist and the industry players in the sector. Subsumed in the content production layer are journalists in 
Bashir: Algorithm Governance Framework

for Media Regulation in Nigerian Media

S y s t e m

Figure 1

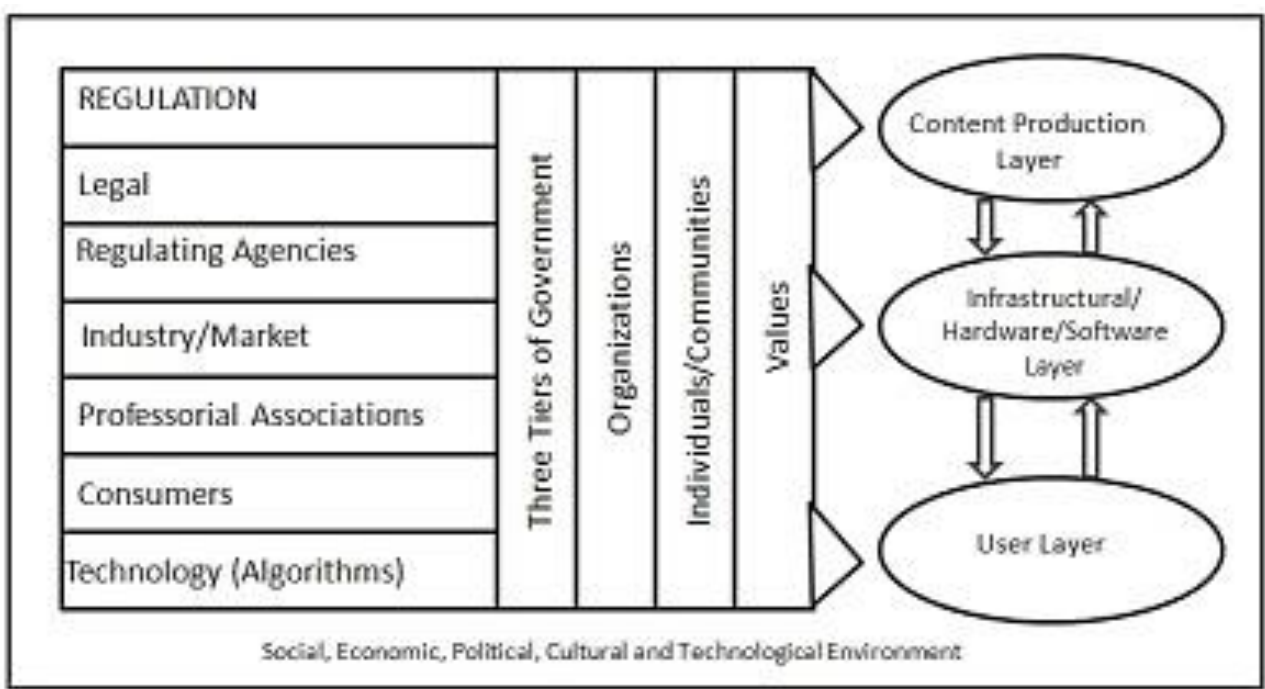

Converged Media Governance Framework for Algorithmic and Mixed Journalism

The conventional and online/multimedia organisations and freelancers. The layer also accommodates bloggers, citizen journalists, social media influencers/content producers, bloggers, proprietors, management, algorithms, amongst others. The content producer in the layer is processed in the second layer using end user hardware and various software (including algorithms) and transmitted through infrastructure layer to public. The conventional print and broadcast technologies and telecommunication system (networks, transmitters, internet, servers, etc) are part of the second layer and as all the three layers are subject to regulations. Whether a content is produced by an individual, an algorithm or a mixture of human and algorithm, the author must be subject to regulation depending on the level of performance and liability. The user layer consists of individuals, groups, or communities receiving or consuming mediated messages. There is symmetric communication flow between the three layers sandwiched infrastructure/hardware/software layer.

On the right side of the framework is the rows and columns. The rows show the layers of regulatory mechanism which range from legal instruments, agencies, industry/market mechanisms, consumers (as groups and individuals) and the users of computer algorithms. In a converged media system, these layers of 
regulation are useful and can be deployed based on need, capacity and functionality. For instance, there should be agency that can regulate the content and/or technologies of online media as it does conventional offline media. In Nigeria today, You Tube TV programmes go unregulated while conventional television stations are barred by the NBC code from showing live programmes from abroad except if they are sports or special broadcast. This shows gap in regulation which this framework hopes to overcome. Similarly, professional and occupational associations like the NUJ, NGE, NAWOJ, SWAN, etc should be able to incorporate practitioner across various platform and when appropriate sanction them when there is an infraction. This implies association too needs to change their present structure and regulations.

In addition, algorithmic technologies can be deployed by the regulatory agencies or industry players following industry sanctioned and legally laid down procedures which should not infringe freedom of expression and of the press. Government agencies in Nigeria are known to be weak in adopting innovation (Adomako and Danso 2014), so this measure will be more appropriate either as a market mechanism or industry self-regulation especially as it relate to online media. In the middle of the framework, vertical columns show that converged media organs and values of regulation which vertically cut across all the layers of regulation and media production consumption chain. The first three layers (all the tiers of government in the country, public and private organisations as well individuals and communities) can be involved in regulation in many ways. The fourth column depicts the values that makes regulations and strengthening it imperative. These values and norms include accountability, transparency, honesty, fairness, freedom, truth, independence, etc. Overall, the regulatory framework is encapsulated within the Nigerian social, economic, cultural, political and cultural environment and should be adapted to contribute towards the fulfilment societal goals and aspirations. The framework must go hand in hand with the needs and challenges of the environment to succeed.

The Converged Media Governance Framework for Nigeria therefore implies the need for adapting Nigeria's media regulation to contemporary media and societal changes. One of which is the recognition of human and non-human actors who are hitherto not well regulated in the current regulatory framework. The prominence of convergence and algorithmic journalism is also necessary in 
Bashir: Algorithm Governance Framework

for Media Regulation in Nigerian Media

Sys t e m

the light of technology changes. In addition, algorithm is also recognized as an agency or tool for media regulation. However, it must be observed that the bottom line of media regulation is behavior of actors in the system. However good a framework is on paper, it will never succeed without understanding, support and cooperation of the actors in the system. This is part of the reason why the current regulatory framework is not having the desired effect.

\section{CONCLUSION}

Algorithm has come to stay in today's communication environment and is shaping a number of activities and processes in various domains one of which is journalism. It can also be observed that algorithms can be used beneficially to enhance journalistic production by extending the human capabilities of journalists and for better services and profits. They can also be used for negative purposes like fake news, violation of privacy, abuse of data, hate speech, and other ethical and legal breaches for which the present regulatory framework in Nigeria is not equipped to regulate. Because of their importance, each society need to critically evaluate how to govern algorithm to tap their potentials and minimize their risks which can be normative and based on case by case. For Nigeria, the study, therefore, recommend the adoption of the Converged Media Governance Framework to accomplish this. The framework recognized algorithmic and human journalism as legitimate and further looks at journalism in the country from three major perspective with different layers and vertical slants operating in the environment. The study therefore recommends that law makers in Nigeria review regulatory instruments to suit contemporary media challenges. Also, journalists in Nigeria, before the advents of massive use of algorithmic software need to be retrained to take advantage of algorithms in newsrooms and to avoid ethical pitfall in using them. Also, journalists in Nigeria need to expand the definition of journalist to incorporate media workers in new platforms like online platforms like blogs, citizen journalists, etc. 


\section{REFERENCES}

Aboh, Blaise. 2020. "Augmented Reporting and the Future of News - Media Career Services." Medium. Retrieved (https://medium.com/ @BlaiseAboh/augmented-reporting-and-the-future-of-news-b06b5ab9b76d).

Adenekan, Samson. 2019. "INEC, CSOs, Others Mull Ways to Tackle Fake News." Premium Times. (https://www.premiumtimesng.com/news/more-news/349115-inec-csosothers-mull-ways-to-tackle-fake-news.html).

Adeyemi, Aderogba. 2013. "Nigerian Media and Corrupt Practices: The Need for Paradigm Shift.” European Scientific Journal 9(1):119-36.

Adomako, Samuel and Albert Danso. 2014. "Regulatory Environment, Environmental Dynamism, Political Ties, and Performance: Study of Entrepreneurial Firms in a Developing Economy." Journal of Small Business and Enterprise Development 21(2):212-30.

Apuke, Oberiri Destiny. 2016. "Information Communication Technology and Citizen Journalism in Nigeria : Pros and Cons." Higher Education of Social Science 11, No.4(4):1-4.

Apuke, Oberiri Destiny. 2018. "The Role of Social Media and Computational Propaganda in Political Communication Campaign." Journal of Language and Communication 5(2).

Balule, Badala Tachilisa. 2016. "Promoting and Safeguarding Media Pluralism in Botswana: An Assessment of Legal Risks." Commonwealth Law Bulletin 42(1):84-104.

Black, Julia, and Robert Baldwin. 2010. "Really Responsive Risk-Based Regulation." Law and Policy 32(2):181-213.

Black, Julia, and Robert Baldwin. 2012. "When Risk-Based Regulation Aims Low: Approaches and Challenges." Regulation and Governance 6(1):2-22.

Doneda, Danilo, and Virgilio A. F. Almeida. 2016. "What Is Algorithm Governance?" IEEE Internet Computing 20(4):60-63.

Ekeanyanwu, Nnamdi Tobechukwu and Nkechi Obianigwe. 2012. "The Nigerian Press, Brown Envelop Syndrome and Media Professionalism: The Missing Link.” Journalism and Mass Communication 2(4):514-29.

Graefe, Andreas. 2016. "Guide to Automated Journalism.” Tow Center for Digital Journalism Report 1-48.

Ifeduba, Emmanuel. 2014. "Holding the Nigerian Press to Account: An Evaluation of Models, Milestones and Sustainability." The Journal of 
International Social Research 7(55):702-11.

Just, Natascha and Michael Latzer. 2017. "Governance by Algorithms: Reality Construction by Algorithmic Selection on the Internet." Media, Culture and Society 39(2):238-58.

Lazer, David, Ryan Kennedy, Gary King, and Alessandro Vespignani. 2014. "The Parable of Google Flu: Traps in Big Data Analysis." Science 343(6176):1203-5.

Lindén, Carl-Gustav. 2017. "Algorithms for Journalism: The Future of News Work." The Journal of Media Innovations 4(1):60-76.

Maho, A. 2013. Towards a Co-Regulatory Framework for Nigeria Media. Berlin: Lambert Academic Publisher.

Manovich, Lev. 2014. "Software Takes Command: Extending the Language of New Media." Choice Reviews Online 51(06):51-3293-51-3293.

Ndlela, Martin N. 2020. "Social Media and Elections in Africa, Volume 1." Pp. 13-38 in Social Media and Elections in Africa, Volume 1. Vol. 1, edited by W. Ndlela, Martin N and Mano. Cham: Palmgrave Macmillan.

Nwabueze, Chinenye. 2010. "Brown Envelopes and the Need for Ethical ReOrientation: Perceptions of Nigerian Journalists." African Communication Research 3(3):497-520.

Onigbinde, Oluseun. 2014. "The Nigerian Budget: Using Creative Technology to Intersect Civic Engagement and Institutional Reform." Field Actions Science Report 2014(11):0-7.

Oparah, Peter Claver. 2015. "So Is Buhari Indeed A Religious Fanatic." Sahara Reporters. Retrieved (http://saharareporters.com/2015/01/27/so-buhariindeed-religious-fanatic-peter-claver-\%09oparah).

Saurwein, Florian, Natascha Just, and Michael Latzer. 2015. "Governance of Algorithms: Options and Limitations." Info 17(6):35-49.

Stromback, Jesper. 2005. "Four Models of Democracy and Their Normative Implications for Journalism.” Journalism Studies 6(3):331-45.

Talabi, Felix Olajide. 2011. "The Internet And Journalism Practice In Nigeria The Internet And Journalism Practice In Nigeria." Global Journal of Human Social Science 11(10):15-20.

Talabi, Felix Olajide and Benjamin Kayode Ogundeji. 2012. "Effects of NonProfessionalism in Nigeria Journalism." Journal of Mass Communication 
and Journalism 02(07).

Valcke, Peggy, Robert Picard, Miklos Sükösd, Beata Klimkiewicz, Brankica Petkovic, Cinzia dal Zotto, and Robin Kerremans. 2010. "The European Media Pluralism Monitor: Bridging Law, Economics and Media Studies as a First Step towards Risk-Based Regulation in Media Markets." Journal of Media Law 2(1):85-113.

Verschuren, Piet and Rob Hartog. 2005. "Evaluation in Design-Oriented Research." Quality and Quantity 39(6):733-62.

Wölker, Anja and Thomas E. Powell. 2018. "Algorithms in the Newsroom? News Readers' Perceived Credibility and Selection of Automated Journalism." Journalism 1(18). 